Eğri, T. / Journal of Yasar University, 2018, 13/49, 68-78

\title{
İşsizlik ve Ekonomik Çıktı İlişkisi: Mısır için Okun Yasası Analizi
}

\section{Relationship Between Unemployment and Economic Output: An Analysis of Okun's Law for Egypt}

\author{
Taha EĞRİ, Kırklareli Üniversitesi, Türkiye, taha.egri@klu.edu.tr
}

Öz: Bu çalışmanın amacı, işsizlik ve ekonomik büyüme arasındaki ters ilişkiyi açıklayan Okun yasasının Misır için geçerliliğinin test edilmesidir. Çalışmada bu amaca ulaşmak için 1970-2016 yılları arasındaki işsizlik ve milli gelir verileri kullanılmışstr. İlk olarak Okun tarafindan ortaya konan model regresyon yöntemi kullanilarak analiz edilmiş, Okun katsaylsı tespit edilmiştir. Daha sonra, değişkenler arasindaki nedensellik ilişkisinin araş̧ırllması amacıyla Granger Nedensellik testi uygulanmıştır. Yapılan analiz sonucunda, Okun tarafindan belirtilen şekilde katsayının işareti negatif bulunmuş ancak katsayı Yasada belirtilenden çok düşük çıkmıştır. İkinci aşamada yapılan nedensellik testinde de iki değişken arasında iliş̧i bulunamamıştır. Sonuç olarak, katsayı Okun Yasasına uygun olarak negatif çıkmış olsa da, hem nedensellik analizi sonucu dikkate alındı̆̆ında hem de tarihsel süreç göz önünde bulundurulduğunda Mısır için Okun Yasasının iktisadi olarak geçerli olamayacağı sonucuna ulaşılmışıtır.

\author{
Anahtar Kelimeler: Okun Yasası, Mısır, İşsizlik, Büyüme, Çıktı, Granger Nedensellik
}

Abstract: The aim of this study is to test the validity of the Okun law for Egypt, which explains the inverse relationship between unemployment and economic growth. Unemployment and output data between 1970 and 2016 were used to reach this aim in the study. First, the model was analyzed by using regression method set out by Okun, and the Okun coefficient was determined. Then, the Granger Causality test was applied to determine the causality relation between the variables. As a result of the analysis made, the sign of the coefficient was found to be negative, as indicated by the model, but the coefficient was too low to be specified. On the other hand, there was no relationship between the two variables in the second-stage causality test. As a result, even though the coefficient was negative in accordance with the Okun Law, when the result of the causality test and Egypt's economic structures are taken into consideration, it is concluded that the Okun Law for Egypt can not be economically viable.

Keywords: Okun Law, Egypt, Unemployment, Economic Growth, Output, Granger Causality

\section{Giriş}

1952 Hür Subaylar devriminden 2011 Arap Ayaklanmalarına kadar siyasal olarak istikrarlı bir yapıya sahip olan Mısır, Arap Ayaklanmalarının etkisiyle kısa bir süre zarfında politik rejim değişiklikleri yaşamıştır. Mübarek’in istifasıyla başlayan süreç, geçici askeri rejim ve ardından seçimle gelen ilk cumhurbaşkanı olan Muhammed Mursi'nin kısa yönetimiyle devam etmiş, sonunda askeri bir darbeyle yönetimi ele geçiren Abdulfettah Al Sisi’nin cumhurbaşkanlığıyla nihayete ermiştir. Mısır'da ayaklanmaları ortaya çıkaran sebepler arasında siyasal gelişmeler kadar yoksulluk, gelir eşitsizliği ve daha da önemlisi işsizlik gibi ekonomik nedenler de bulunmaktadır. Yaşanan ekonomik krizlerin ve dalgalanmaların da etkisiyle Mısır, uzun yıllar boyunca yüksek oranlı işsizlik problemiyle karşı karşıya kalmıştır. 1990'larda, ülkede gerçekleştirilen ekonomik reformlar ve ülke ekonomisine şırınga edilen dış kaynakların etkisiyle ekonomik büyümenin yüksek oranlarda seyretmesine rağmen emek piyasasında hedeflenen başarılar elde edilememiştir. Bu bağlamda, bu çalışmada, toplumsal tepkilerin merkezinde yer alan konulardan biri olan işsizliğin ekonomik büyümeyle olan ilişkisi ele alınmaktadır. 1962 yılında Arthur Okun’un Amerika Birleşik Devletleri için yapmış olduğu çalışmayla ortaya koyduğu ve literatürde Okun Yasası olarak bilinen işsizlik-büyüme ilişkisi Mısır için test edilecektir. İktisadi büyümenin işsizliği düşürdüğü gözlemiyle araştırmasını gerçekleştiren Okun, büyüme ve işsizlik arasındaki ters yönlü ilişkiyi çalışmasında ortaya koymuştur. Makalenin birinci bölümünde, Mısır'da yaşanan işsizlik ve büyüme rakamları kısaca ele alınacaktır. Çalışmanın ikinci bölümünde ise, teorik çerçeve ve literatür tartışılarak, Okun tarafından ortaya konan model, regresyon yöntemi kullanılarak analiz edilecektir. 
Eğri, T. / Journal of Yasar University, 2018, 13/49, 68-78

\section{Mısır'da Ekonomik Büyüme ve İşsizlik}

Mısır'da işsizlik sorunu, devletin ekonomide aktif istihdam politikalarına rağmen uzun yıllardır devam etmektedir. Aşağıdaki grafikte 1990-2014 yılları arasında oluşan işsizlik oranları ve toplam iş gücünün eğilimi verilmiştir. İlgili dönemde işgücü miktarı düzenli olarak artış göstermekle birlikte toplam işsizlik oranı \%10 düzeyinde seyretmektedir. Özellikle 2000'lerin ilk yarısında işsizlik oranlarının artış gösterdiği, 2007-2010 arasında ise düşüş yaşandığı görülmektedir. Ancak, 2010 sonrası ortaya çıkan siyasi istikrarsızlıkların da etkisiyle hızlı bir artış yaşanarak \%14 düzeyine çıkmışır. Diğer taraftan, artan nüfusa ve iş gücüne yeni katılanların istihdamında yaşanan sıkıntılar dolayısıyla genç işsizliği daha yüksek oranlara sahiptir. Özellikle 2000'lerin başından itibaren artışa geçen genç işsizliği ayaklanmaların hemen arifesinde $\% 25$ seviyesinde iken 2014 y1lında \%40 düzeyine ulaşmıștır. 2008 Küresel Krizin etkileri ile yükselişe geçen işsizlik oranları 2010 sonrası ortaya çıkan siyasi gelişmelerle daha da fazla artış kaydetmiştir. Diğer taraftan, işsizlik olgusu dikkatle ele alınmalıdır. Resmi rakamların iş piyasasındaki gerçek durumu tam yansıtmadığı ve kayıt dışılık nedeniyle iş kayıpları ve işsizliğin daha büyük bir problem oluşturduğu da iddia edilmektedir (Ikram 2006, 213). 2004 yılında hayata geçirilen ekonomik reform politikaları ile artan yurtdışı kaynakların da etkisiyle emek piyasasında bir miktar canlanma yaşanmış ancak 2008 Krizi ile işsizlik oranları hızlı bir şekilde artmıştır. Uygulanan neoliberal ekonomi politikaları ile birlikte özelleştirmelerin hız kazanması ve kamu istihdamının düşürülmesiyle ortaya çıkan açığı, özel sektör dolduramamıştır (Bargawi 2014, 225). Ekonomik büyüme önemli oranda sağlanmış olsa da artan kayıt dışılık hem emek piyasasını etkilemiş hem de gelir artışı ve diğer sosyal haklardan faydalanılmasının önüne geçerek yoksulluğun derinleşmesine neden olmuştur (Bargawi 2014, 225).

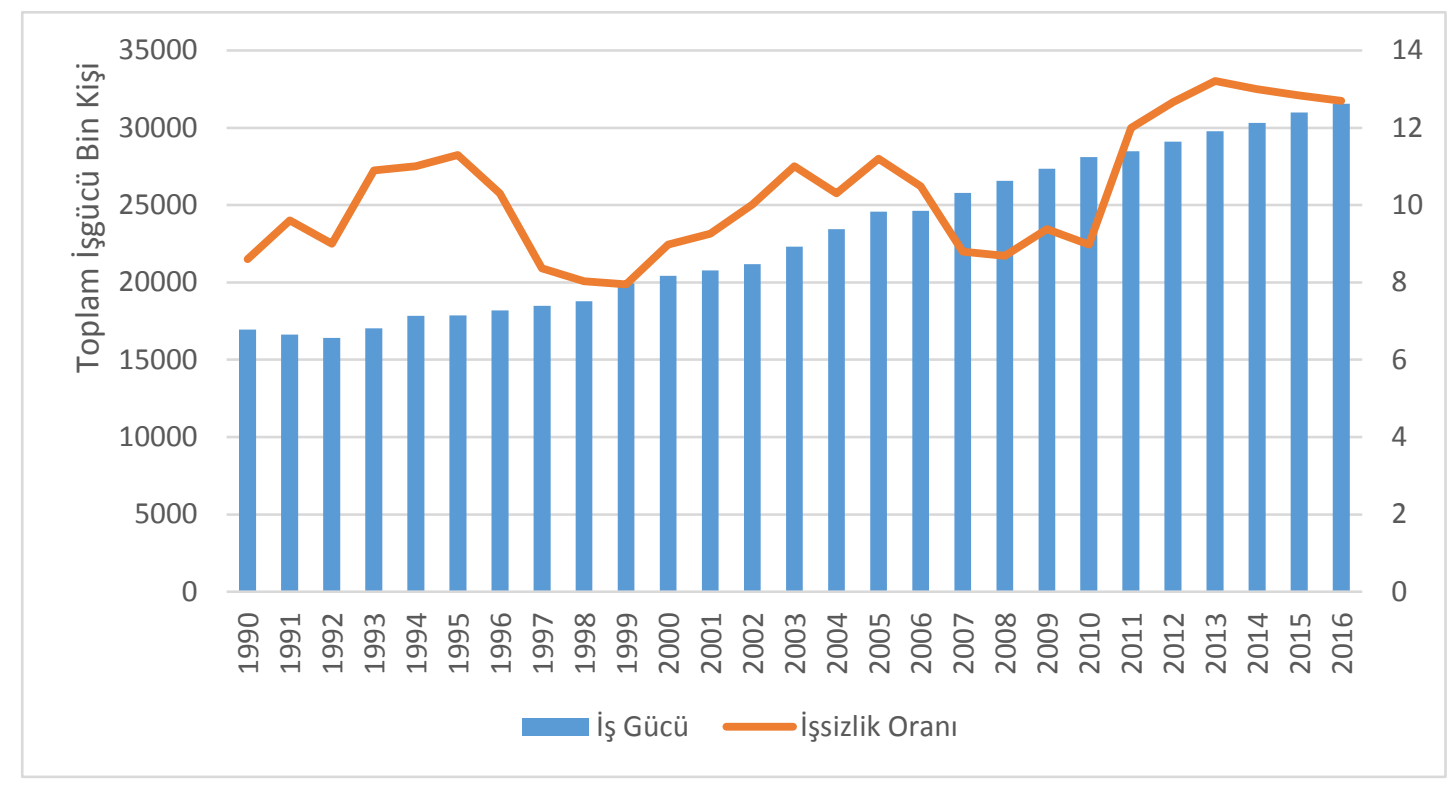

Grafik 1. Toplam işgücü ve İşsizlik Oranları (1990-2016)

İstihdam piyasasında ortaya çıkan diğer bir problem küçük işletmelerin artan payı olarak gösterilmektedir. On ve daha az işçi çalıştıran bu işletmelerin iş piyasasındaki payının artması, kayıt dışılığın yükselmesine ve ücretlerde düşüş ile sosyal haklarda kayıpların doğmasına yol açmaktadır (Bargawi 2014, 225). İstihdam ile yaşanan sıkıntıların ve rahatsızlıkların bir diğer alanı da genç ve eğitimli kesimin işsiz kalmasıdır. Cemal Abdul Nasır döneminde her üniversite mezununa iş garantisi politikası Hüsnü Mübarek döneminde kaldırılmıştır. Artan üniversite mezunu sayısına rağmen iş piyasası ihtiyaçları ile paralelliğin sağlanamaması mezunlar arasında işsizliğin artmasına yol açmıştır (Abdih 2011, 37). 2009 yılında toplam işsizliğin \%35,5'i, 2010 yılında ise \%39,7'si yükseköğrenim mezunları oluşturmaktadır. Diğer taraftan ortaöğretim düzeyinde eğitime sahip olanların payı da \%50’ye çıkmıştır (World Bank 2016).

Reformlarla birlikte büyüme trendi yakalayan ekonomide, artan nüfusa paralel olarak işsizlik önemli bir sorun olarak ülke gündeminde yer almaktadır. \%10 seviyesinde olan ișsizlik oranları, 2005 sonrası yaşanan ekonomik gelişmelerle birlikte \%8,7 seviyesine kadar düşürülmüştür. Toplam işgücünün zaman içerisinde artmasına rağmen işsizlik oranlarının düşürülmesi ancak yeni istihdam imkânlarının ekonomik büyümeye paralel olarak yaratılmasıyla ortaya çıkmıştır. Lâkin 
ekonomik büyümenin özellikle düşük üretkenliğe sahip imalat, ticaret ve restoran gibi hizmet sektörlerinde yaşanmış olması, işsizlik sorunun devam etmesine ve sürdürülebilir bir istihdamın olamamasına neden olmuştur (Alissa 2007, 12). Reformlar aracılığıyla kamu istihdamının azaltılması amaçlansa da bu hedef yeterli düzeyde gerçekleştirilememiştir. 1990'da özel sektörün istihdamdaki payı \%67 iken, 2005'de ancak \%70'e çıkabilmiştir. Kamu iktisadi teşekküllerinin istihdam oran1, \%10'dan \%5'e düşmüş olsa da, kamu istihdamı \%22'den \%26'ya çıkmıştır (Alissa 2007, 12). İşsizlik oranlarında 2004 sonrası yaşanan kısmi iyileşme, küresel kriz ve içsel karışıklıklarla birlikte hızlı bir gerileme göstermiş ve işsizlik oranı \%13 oranına kadar çıkmışıtır. Belirtilen işsizlik oranları resmi kayıtlı istatistikleri ifade etmektedir. Ancak kayıt dış1 ekonominin büyük bir paya sahip olduğu Mısır'da istihdam ve işsizlik olgusu, toplumsal ve ekonomik olarak çok farklı etkilere sahiptir. Yapılan bir hesaplamaya göre 2005 yılında kayıt dışı istihdamın toplam istihdamın \%47'sine tekabül edecek şekilde 9 milyon kişiye ulaştı̆̆ belirtilmektedir (El-Megharbel 2008, 181). Kayıt dışı istihdamın yüksek olması özellikle kriz dönemlerinde ortaya çıkan işsizlik durumunun ve sosyal problemlerin yanlış okunmasına neden olmaktadır. Yaşanan iş kayıpları resmi istatistiklerin daha üstünde gerçekleşmekte ve sosyal problemler daha geniş bir toplumsal kesimi etkilemektedir.

Ekonomik büyüme açısından ise Mısır ekonomisi 1970'lerden itibaren dalgalı ancak aşağı yönlü bir trende sahiptir. 1970 petrol krizinin etkili olduğu ilk yıllarda düşen büyüme rakamları Enver Sedat'ın Açılım (infitah) politikalarıyla birlikte hızlı bir şekilde yükselişe geçmiştir. Kapalı bir ekonomiye sahip Mısır, iç talep etkisiyle 1973-1986 arasında \%10 ortalama büyüme gerçekleştirmiştir. Ancak, ithalata dayalı bu yapı 1980'lerin ikinci yarısıyla makroekonomik dengede bozulmalara yol açmış ve iktisadi problemleri doğurmuştur. Büyüme rakamları \%3-4 civarında seyretmiştir. 1980'lerin son yıllarında ortaya çıkan makroekonomik problemler ve uluslararası kurumların baskısı karşısında Mısır hükümeti reformlar hususunda adımlar atmak zorunda kalmıştır. İktisadi sorunlara çözüm arayışı ve başta IMF olmak üzere uluslararası kreditörlerin ikna edilmesi amaciyla Mart 1990 tarihinde "Ekonomik Reform ve Yapısal Uyum Programı" (Economic Reform and Structural Adjustment Program-ERSAP) başlıklı bir eylem planı hazırlanmıştır. 1990 yılından itibaren uygulanmaya başlayan ve 1997 yılında IMF programının bitmesine kadar devam eden reform sürecin Mısır makroekonomik alanda önemli gelişmeler kaydetmiş̧ir. Ekonomik büyüme oranları 90'ların ilk yıllarında yavaşlama göstermiş ancak daha sonra hızla toparlanarak 1990’ların sonlarında \%7 seviyelerine kadar çıkmıştır (Ikram 2006, 66)

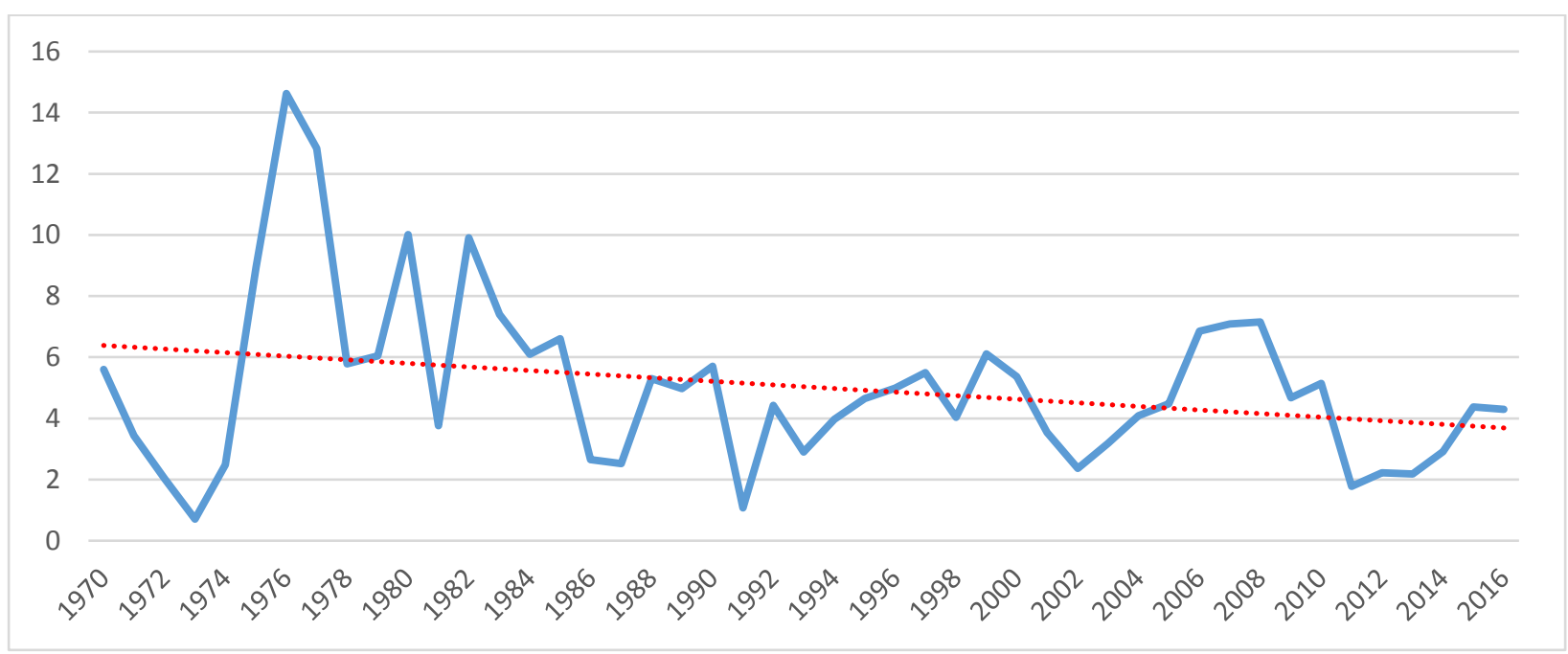

Grafik 2. 1970-2016 Büyüme Rakamları

2000'li yıllara ekonomik sorunlarla giren ve ekonomik büyüme oranları \%3 seviyesine kadar düşen Misır ekonomisi 2004 yılından göreve gelen Ahmed Nazif hükümetinin aldığı reform kararları ile yeniden hız kazanmıştır. 2005-2009 yılları arasında yıllık \%7 seviyesinde büyüme yaşanmıştır. Yaşanan hızlı büyümede özellikle imalat, inşaat, emlak ve turizm sektörlerinde yaşanan gelişmeler önemli bir paya sahiptir. Oluşan reform ortamında özel yatırımların ve tüketimin artması büyümenin motoru haline gelmiştir. Özellikle vergi reformunun özel sektörü canlandırıcı bir etkisi olmuştur (AfDB and OECD 2008, 274). İç talepteki yıllık artış oranı 2003 yılındaki \%1,3 düzeyinden 2007 yılında \%09,9'a kadar çıkmıştır. Benzer bir şekilde yatırımlarda hızlanmış, 2007 yılında \%3,7 oranında artış göstermiştir. Ancak, 2008 yılında yaşanan küresel ekonomik krizin etkisiyle büyüme oranları yavaşlamaya başlamıştır. 2008 yılında \%7,2 olan büyüme oranı 2009 yılında \%4,2'ye gerilemiştir. Yaşanan yavaşlamaya, 2010 yılında ortaya çıkan Arap Ayaklanmaları da eklenince büyüme rakamları 2011 yılı itibariyle \%2 civarına düşmüştür. 2015 ve 2016 yıllarında hükümetin almış olduğu önlemler ve yatırımlar sayesinde büyüme rakamları bir miktar toparlanma göstermiştir. 
Eğri, T. / Journal of Yasar University, 2018, 13/49, 68-78

\section{Teorik Arka Plan}

Arthur Okun 1962'de yayınladığı makaleyle ABD için İkinci Dünya Savaşı sonrası işsizlik ve ekonomik büyüme arasındaki ilişkiyi incelemiştir. Makale büyüme ve işsizlik arasındaki ilişkinin ele alındığı çalışmalar için mihenk taşı olmuş ve literatüre Okun Yasası olarak geçmiştir. Yasa; büyüme ve işsizlik oranlarındaki çevrimsel dalgalanmaların ters ilişkisini ortaya koymaktadır. Şok ekonomik çıktının potansiyel seviyesinin etrafında dalgalanmasına neden olmakta, bu da ters yönlü olarak firmaların istihdamlarını artırmalarına veya azaltmalarına yol açmaktadır. Bu ilişki şu şekilde gösterilmektedir (Ball et al. 2016):

$u_{t}-u_{t}^{*}=\beta\left(y_{t}-y_{t}^{*}\right)+\varepsilon_{t}$

$u_{t}^{*}$ ve $y_{t}^{*}$ sırasıyla işsizliğin trend değeri ya da başka bir ifadeyle potansiyel değerini ve çıktının logaritmik değerini göstermektedir. Hata terimi ise dalgalanmalardan kaynaklı, üretimdeki değişiklikler veya işgücüne katılım oranındaki değişimler gibi model dışı etkenleri içermektedir. $\beta$ Katsayısı ise aradaki ilişkinin büyüklüğünü vermektedir.

Okun denkleminin diğer bir versiyonu ise işsizlik ve büyüme oranlarındaki dönemsel değişimler arasındaki ilişkiyi ele almaktadir.

$\Delta u_{t}=\alpha+\gamma \Delta y_{t}+\omega_{t}$

$\Delta$ İşsizlik ve büyüme rakamlarındaki değişimi ifade etmektedir.

Okun Yasası "Açık" modeli olarak adlandırılan birinci denklemle ya da "fark" modeli olarak isimlendirilen ikinci denklemle hesaplamak mümkündür. Birinci denklemde Okun, milli gelirin ve işsizliğin ortalama ya da potansiyel değerini ve reel değerlerin potansiyel değerden sapma oranlarını hesaplayarak bu iki değişken arasındaki ilişkiyi incelemiştir. İkinci denklemde ise Okun, büyüme oranlarındaki değişim ile işsizlik arasındaki değişimin ilişkisini ele almıştır. 1948-1960 yılları arasında hesapladığı modelde Okun $\% 4$ büyüme üzerindeki her bir \% 1 büyümenin işsizliği $\% 0,7$ oranında düşürdüğü sonucuna ulaşmıştır (Arshad 2007, 11).

Burada dikkat edilmesi gereken husus ülkelerin çıktı potansiyellerine göre katsayıların değişiklik gösterebileceğidir. Örneğin, Göçer (2015) 2001-2015 dönemi için \% 4.3’ü aşan her \%1 puanlık büyümenin, işsizliği \%0.11 puan azalttığ1 sonucuna ulaşmıştır (Göçer 2015).

\section{Literatür Araştırması}

İşsizlik ve büyüme arasındaki ilişkiyi inceleyen çalışmalar daha önce de bahsedildiği üzere Okun'un 1962 yıllndaki çalışmasıyla farklı bir yapıya evirilmiştir (Okun 1962). Okun sonrası yapılan çalışmalarda ilişkinin varlığı yanında katsayının büyüklüğünün tespit edilmesi üzerinde de yoğunlaşılmaktadır. Örneğin; Prachowny (1993), Amerika Birleşik Devletleri (ABD)'ne ait 1975-1988 çeyrek dönemlik verilerle yapmış olduğu çalışmada iki değişken arasındaki ilişkiyi tespit etmiş olsa da katsayıyı Okun bulduğu şekilde mutlak 3 değerinin çok altında, $-0,67$ olarak bulmuştur. Weber (1995) yine ABD'ye ait 1948-1988 arası çeyrek verilerle Okun Yasasını ele almış ve uzun dönem için Okun katsayısına yakın değerlere ulaşmıştır. Ancak kısa dönemler için ele aldığı dört farklı modelde katsayıların daha küçük olduğu sonucuna ulaşmıştır. Yine ABD’ye ait 1947-1992 dönemi çeyrek dönemlik verilerini ele alan Moosa (1999) işsizlik ve çıktı verisinin trendden arındırılmış değerlerini kullanmış, model ister statik ister dinamik olsun, katsayıyı 3'ün üzerinde tespit etmiş̧ir. Diğer taraftan, Attfield ve Silverstone (1997) ile Coen ve Hickman (2006) ise Birleşik Devletler için Okun katsayısını sırasıyla -2.25 ve -1.90 olarak bulmuşlardır.

Yakın zamanlarda ABD verileriyle yapılan bir çalışma ise Grant (2017)'ye aittir. 1948-2016 dönemine ait çeyrek dönem verileriyle yapılan çalışmada açık modeli kullanılmış ve ilişkinin zaman içerisindeki seyri ele alınmıştır. Çalışmada Okun katsayısının zaman farkına sahip olduğu öne sürülmüştür. Özellikle 1980'ler öncesinde katsayının -2,5 ile -2 arasında, 2008 krizi öncesinde $-1,5$ ile -1 arasında dalgalandığı bulunmuştur. Katsayının özellikle günümüze kadar giderek büyüdüğü ve $-0,5$ 'e kadar çıktığı sonucuna ulaşılmıştır. Okun katsayısının zamana bağlı değişim konusunda Berger, Everaert \& Vierke (2016) tarafından yapılan çalışmada 1959-2014 dönemi ele alınmıştır. Çalışmada katsayının zaman içerisinde farklılaştığı tespit edilse de, genel olarak tarihsel ortalamada seyrettiği sonucuna ulaşılmıştır.

ABD dışında çeşitli ülke örneklerini ele alan çalışmalarda da çok farklı sonuçlara ulaşılmıştır. Attfield ve Silverstone (1998) İngiltere için yaptıkları çalışmada VECM yaklaşımını kullanarak analiz gerçekleştirmiş ve katsayıyı $-1,45$ bulmuşlardır. Moosa (1997) G7 ülkeleri için Okun katsayısının geçerliği olduğu ancak ülkeler arasında farklılaştığını tespit etmiş̧lerdir. Lee (2000) Hodrick-Prescott filtresi kullanarak hesapladığı modelde 16 OECD ülkesi için Okun katsayısı 
hesaplamış ve Japonya için katsayıyı -6,55 bulurken, İtalya için -0,57 hesaplamıştır. Sonuçta ele alınan ülkeler için geniş bir aralıkta farklı değerlere ulaşmıştır. Tatoğlu (2011) 19 Avrupa ülkesi için yaptığı çalışmada Okun katsayısını test etmiş ve 0,70 olarak bulmuştur. Christopoulos (2004) ise Yunanistan için -1,4 sonucuna ulaşmıştır. Izyumov and Vahaly (2002) ise Avrupa Birliği üyesi ülkeler için -1,32 ve üye olmayan Avrupa ülkeleri için -0,70 değerini hesaplamıştır. Adanu (2005) ise 10 Kanada bölgesi için yaptığı çalışmada Okun katsayısını -1,58 olarak bulmuştur. Loria (2007) Meksika için yapmış olduğu çalışmada Kalman filtresi kullanmış ve her iki modeli de hesaplamıştır. Çeyrek dönem verileri ve yıllık verilerle karşılaştırmalı çalışmış ve katsayıyı 2,35 ile 2,58 arasında değişen değerlerde hesaplamıştır.

Petkov (2008) ARDL modeli kullandığı çalışmasında Hodrick-Prescott filtresi kullanarak trend değerleri hesaplmıştır. İşsizlik trendini HP filtresiyle hesaplayarak hata düzeltme modeli (ECM) kullanmıştır. Çalışmasında işsizlik ve çıktı arasında dinamik ilişkinin varlığını tespit etmiştir. Economou \& Psarianos (2016) 13 Avrupa Birliği ülkesine ait 1993-2014 dönemi çeyrek dönem verilerini kullanarak Okun yasasını ele almışlardır. Ele alınan fark modeline göre katsayı -0.073 ve açık modeline göre -0.209 bulunmuştur. Okun yasasına paralel olarak sonuçlara ulaşan bu çalışmaların yanında literatürde ilişkinin doğrusal olmadığı, değişkenlerin asimetrik özellik gösterdiğini bulan araştırmalar da bulunmaktadır. Viren (2001) ve Fouquau (2008) 20 OECD ülke örneğinde; Harris ve Silverstone (2001) 7 OECD ülke örneğinde; Beaton (2010) Kanada ve ABD için ve Barışık vd. (2010) Türkiye için büyüme ve işsizlik arasında ilişkinin asimetrik olduğunu iddia etmişlerdir. 2011-2015 dönemine ait verilerle 85 ülke gibi geniş bir örneklemi ele alarak yaptığı çalışmayla Hooper (2017) Okun yasasının geçerli olduğunu iddia etmiştir. Yapmış olduğu çalışmada işsizlikte yaşanacak olan her \%1 düşüşün büyümeyi $\% 0,25$ oranında artıracağını belirtmiştir.

Tekil ülke örnekleri bağlamında Türkiye'deki ilişkiyi ele alan çalışmalar da bulunmaktadır. Bu çalışmaların bir kısmı iki değişken arasındaki ilişkiyi tespit etmeye çalışmış bir kısmı da Okun katsayısını hesaplamışlardır. Eser (2014) Türkiye için yapmış olduğu çalışmada eş bütünleşme analizi gerçekleştirmiş ve Okun yasasının geçerli olduğunu bulmuşlardır. Benzer şekilde Akay vd. Türkiye için 1969-2014 dönemini ele almış ve Markov Rejim Değişim modeli kullanarak yaptıkları çalışmada kısa ve uzun dönemde ilişkinin varlığını tespit etmişlerdir. Şenturk \& Akbas (2014) Türkiye için 20052012 dönemine ait aylık verileri kullanarak Toda-Yamamoto ve bootstrap nedensellik testleri gerçekleştirmiştir. Çalışmada, sanayi üretim endeksi ve enflasyon oranı ile işsizlik oranı arasında çift yönlü nedensellik ilişkisi tespit edilmiştir. Çondur \& Bölükbaş (2014) 2000-2010 dönemine ait çeyrek dönem verilerine ele alarak genç işsizliğiyle GSYİH ve ÜFE arasındaki nedensellik ilişkisini araştırmışlardır. Sonuçta genç işsizlikten GSYİH'ya ve ÜFE'den genç işsizliğe doğru bir nedensellik ilişkisi saptamıșlardır. Yilmaz (2005) 1978-2004 dönemine ait verilerle işsizlik ve büyüme arasındaki nedensellik ilişkisini ele almıştır. Granger nedensellik testi ve Hsiao tarafından geliştirilen Son Tahmin Hata Kriteri (Final Prediction Error) yöntemiyle yapılan analiz sonucu Türkiye ekonomisinde büyüme oranı ile işsizlik oranı arasında karşılıklı bir nedensellik ilişkisi bulunmamıştır. Nedensellik ilişkisinin yönü sadece işsizlik oranından büyüme oranına doğru bulunduğu, büyüme oranından işsizlik oranına doğru bir nedensellik ilişkisi ise bulunmadığı ifade edilmişsir. Kızılgöl (2006) tarafından Türkiye'ye ait 1988-2006 dönemini kapsayan altı aylık veriler kullanılarak iki değişken arasındaki eşbütünleşme ilişsisi tahmin edilmiştir. Elde edilen sonuçlara göre, büyüme oranı ile işsizlik oranı arasında tek bir uzun dönem veya denge ilișkisi bulunmuştur. Hsiao (FPE kriteri) ve VECM yardımıyla yapılan Granger nedensellik testleri, sadece ișsizlik oranından büyüme oranına doğru bir nedensellik ilişsisinin varlı̆̆ını gösterdiği iddia edilmiştir. Son olarak yakın zamanda Mucuk, Edirneligil, \& Gerçeker (2017) tarafından yapılan çalışmada 2002-2014 yıllarına ait veriler ele alınmış ve VCEM analizi gerçekleştirilmiştir. Çalışma sonucundan değişkenler arasında uzun dönemde eş bütünleşme olmadığı, diğer bir ifadeyle uzun dönem ilişkin bulunmadığı ifade edilmiş ve Okun yasasının geçerli olmadığı öne sürülmüştür.

Literatürde Mısır'daki işsizlik sorunsalı hakkında farklı çalışmalar yer alsa da Okun yasasının testi konusunda çalışma sayısı azdır. Malec vd. yaptıkları çalışmada Mısır için 2000-2013 dönemi için Okun yasasını test etmişler ve büyüme ve işsizlik arasında ilişkinin varlı̆̆ını tespit etmiş ve katsayısı 0,91 olarak hesaplamışlardır.

\section{Model ve Data}

Bu çalışmada Mısır'a ait 1970-2016 arası döneme ait işsizlik ve büyüme verileri kullanılarak Okun yasasının geçerliliği araştırılacaktır. Literatürde bölgesel örneklerle yapılan çalışmalar mevcut olmakla birlikte farklı katsayılar bulunmaktadır. Malec vd. tarafindan yapılan çalışma 2000 sonrasını ele almakta, ekonomik ve siyasal krizlerin olduğu kısa bir dönemi içermektedir. Bu bağlamda, daha uzun bir dönem için ilişkinin test edilmesi gerekmektedir. Bu bağlamda, Mısır'a ait işsizlik ve reel büyüme oranı verileri Dünya Bankası Kalkınma Veri tabanından (World Development Indicators) elde edilmiştir. 


\subsection{Ekonometrik Yöntem}

Okun Yasasına ait iki model olduğu yukarıda belirtilmişti. Bu çalışmada 1 no.lu açık denkleminin kullanılması tercih edilmiştir.

$u_{t}-u_{t}^{*}=\beta\left(y_{t}-y_{t}^{*}\right)+\varepsilon_{t}$

$u_{t}^{*}$ ve $y_{t}^{*}$ sırasıyla işsizliğin trend değeri ya da başka bir ifadeyle potansiyel değerini ve çıktının logaritmik değerini göstermektedir. Hata terimi ise dalgalanmalardan kaynaklı, üretimdeki değişiklikler veya işgücüne katılım oranındaki değişimler gibi model dışı etkenleri içermektedir. $\beta$ Katsayısı ise aradaki ilişkinin büyüklüğünü vermektedir.

İşsizlik ve milli gelirin potansiyel değerlerinin bulunması için literatürde farklı yöntemler önerilmiştir. Çeşitli trendden arındırma yöntemleri bulunmakla birlikte, Durech vd. tarafından kullanılan yöntem takip edilerek HP Filtresi kullanılmışır (Durech et al. 2014). Ayrıca İspanya üzerinde yapılan bir çalışmada yazarlar üç farklı trendden arındırma yöntemini de kullanarak potansiyel değerleri hesaplamışlardır. İkinci aşama Okun yasasını testinde ise HP Filtresi ile devam etmişlerdir (Villaverde and Maza 2009). Ayrıca Arshad İsviçre için yapmış olduğu çalışmada da benzer şekilde HP filtresi kullanarak modeli oluşturmuştur (Arshad 2007, 17). Potansiyel değerlerin hesaplanmasının zorluğu dolayısıyla serilerin trendden arındırılarak kullanılması literatürde kullanılan bir yöntem olarak bu çalışmada da tercih edilmiştir.

Modelin test edilmesi için öncelikle HP filtresi kullanılarak trendden arındırılmış işsizlik ve büyüme verileri hesaplanmıştır. Modelin sağlıklı bir şekilde tahmin edilebilmesi için " $u_{t}-u_{t}^{*}$ ve " $y_{t}-y_{t}^{*}$ " fark değerlerinin durağan olması gerekmektedir. Bundan dolayı ikinci aşamada durağanlık testi yapılmıştır.

Tablo 1. Durağanlık Testi

\begin{tabular}{|l|l|l|l|l|}
\hline \multirow{2}{*}{} & \multicolumn{2}{|c|}{$\begin{array}{c}\text { ADF (Augmented Dickey-Fuller) } \\
\text { Birim Kök Testi }\end{array}$} & \multicolumn{2}{c|}{ PP (Phillips-Perron) Birim Kök Testi } \\
\hline \multirow{2}{*}{ U } & Test İstatistiği & Kritik Değer & Test İstatistiği & Kritik Değer \\
& $-3.798(0.0029)$ & -3.607 & $-24.724(0.0018)$ & -18.628 \\
& & -2.941 & & -13.172 \\
& & -2.605 & & -10.620 \\
\hline Y & $-4.979(0.000)$ & 3.607 & $-30.625(0.0000)$ & -18.628 \\
& & -2.941 & & -13.172 \\
& & -2.605 & & -10.620 \\
\hline
\end{tabular}

Not: Parantez içerisindeki değerler olasılık değerleridir. ADF testi Schwarz bilgi kriteri (SIC) dikkate alınarak. PP testinde ise Newey-West optimal uyarlama gecikmeleridir.

Tabloda verilen $U$ değeri işsizlik serisinin HP filtresi kullanılarak elde edilen " $u_{t}-u_{t}^{*}$ " değerini; $\mathrm{Y}$ ise aynı şekilde hesaplanan milli gelir açığını " $y_{t}-y_{t}^{*}$ ifade etmektedir. Tabloda verilen değerlere göre test istatistiği kritik değerlerden küçük olduğundan dolayı birim kökün var olduğu kabul eden Ho hipotezi reddedilmekte ve serinin durağan olduğu anlaşılmaktadır. ADF ve PP testlerinin her ikisinde de serilerin durağan olduğu anlaşılmakta ve HP filtresinin başarılı bir şekilde serileri trendden arındırdığı anlaşılmaktadır.

Tablo 2. Model Sonuçları

\begin{tabular}{|rrrrrrr|}
\hline $\mathrm{U}$ & Coef. & Robust Std. Err. & $\mathrm{t}$ & \multicolumn{2}{c|}{$\mathrm{P}>|\mathrm{t}|$} & \multicolumn{2}{c|}{ [95\% Conf. Interval] } \\
\hline $\mathrm{Y}$ & -.0819608 & .0457476 & -1.79 & 0.080 & -.174046 & .0101244 \\
\hline \multicolumn{3}{|c}{$\mathrm{F}(1,46)=3.21$} & \multicolumn{3}{r}{ Prob $>\mathrm{F}=0.0798$} \\
\hline
\end{tabular}

Model sonuçları incelendiğinde katsayının Okun Yasasına uygun şekilde negatif çıktığı görülmektedir. Diğer taraftan katsayı yaklaşık -0.082 çıkmıştır. Her ne kadar katsayı işareti literatürde belirtilen şekliyle çıkmış olsa da katsayının düşük 
olması ilişkinin zayıf olduğunu göstermektedir. Milli gelir açığında meydana gelecek \%1'lik bir değişme işsizlik açığında göz ardı edilebilecek bir düşüşe yol açmaktadır. Ayrıca modelin \%5 düzeyde istatistiksel olarak anlamlı çıkmaması ancak $\% 10$ düzeyde anlamlı olması nedeniyle modele nedensellik testlerinin de uygulanmasına karar verilmiştir. Okun yasası testi için kullanılan seriler $\mathrm{U}$ ve $\mathrm{Y}$ işsizlik açığı, milli gelir açığı iken, nedensellik ilişkisinin analiz edilmesi için işsizlik (unemp) ve milli gelirin doğal logaritması (lgdp) kullanılmıştır.

Tablo 3. Nedensellik Analizi için Durağanlık Testleri

\begin{tabular}{|c|l|l|l|l|}
\hline \multirow{2}{*}{} & \multicolumn{2}{|c|}{$\begin{array}{c}\text { ADF (Augmented Dickey- } \\
\text { Fuller) Birim Kök Testi }\end{array}$} & \multicolumn{2}{c|}{ PP (Phillips-Perron) Birim Kök } \\
& Testi \\
\hline & Test İstatistiği & Kritik Değer & Test İstatistiği & Kritik Değer \\
\hline Unemp & $-1.078(0.7238)$ & -3.607 & $-2.126(0.7268)$ & -18.628 \\
& & -2.941 & & -13.172 \\
& & -2.605 & & -10.620 \\
\hline LGDP & $-2.065(0.2590)$ & 3.607 & $-0.568(0.4691)$ & -18.628 \\
& & -2.941 & & -13.172 \\
& & -2.605 & & -10.620 \\
\hline DUnemp & $-6.995(0.000)$ & -3.607 & $-44.284(0.000)$ & -18.628 \\
& & -2.941 & & -13.172 \\
& & -2.605 & & -10.620 \\
\hline DLGDP & $-3.647(0.0049)$ & 3.607 & -21.020 & -18.628 \\
& & -2.941 & $(0.0050)$ & -13.172 \\
& & -2.605 & & -10.620 \\
\hline
\end{tabular}

Not: Parantez içerisindeki değerler olasılık değerleridir. ADF testi Schwarz bilgi kriteri (SIC) dikkate alınarak. PP testinde ise Newey-West optimal uyarlama gecikmeleridir.

Tablo 3'de işsizlik serisinin (unemp) ve çıktı serisinin doğal logaritmasının (lgdp) düzeyde ve birinci farkları (DUnemp DLGDP) alınarak yapılan durağanlık testleri sonuçları verilmektedir. Tablodaki değerlerden de görüleceği üzere seriler düzey değerlerinde durağan değil iken birinci farkları alındığında durağan hale gelmektedirler. Diğer bir ifadeyle seriler I(1)'dir. Ayrica seriler Breusch-Godfrey ve Durbin-Watson testleriyle sınanarak aralarında bir otokorelasyon sorunu olup olmadığına araştırılmış ve sonuçta otokorelasyon problemi bulunamamıştır.

Serilerin durağanlığının tespiti sonrasında, değiş̧kenler arasında uzun dönemli bir ilişki olup olmadığ Johansen Eş bütünleşme testi ile sınanmıştır. Tablo 4'de verilen test sonuçlarına göre her iki test de değişkenler arasında uzun dönem eş bütünleşme yoktur sıfir hipotezini reddetmemektedir. Bu sebeple, Mısır'da 1970-2016 yılları arasında milli gelir ve işsizlik arasında uzun dönemli bir ilişkinin söz konusu olmadığı anlaşılmaktadır.

Tablo 4. Eş Bütünleşme Test Sonuçları

\begin{tabular}{|l|l|l|l|l|}
\hline \multicolumn{2}{|l|}{ İz İstatistiği } & \multicolumn{2}{l|}{ Maksimum Özdeğer İstatistiği } \\
\hline $\begin{array}{l}\text { Eşbütünleşik Vektör } \\
\text { Sayısı }\end{array}$ & İz İstatistiği & $\begin{array}{l}\text { \%10 Kritik } \\
\text { Değer }\end{array}$ & $\begin{array}{l}\text { Maksimum } \\
\text { Özdeğer İstatistiği }\end{array}$ & $\begin{array}{l}\text { \%10Kritik } \\
\text { Değer }\end{array}$ \\
\hline 0 & 11.7526 & 15.41 & 8.8235 & 14.07 \\
\hline 1 & 2.9291 & 3.76 & 2.9291 & 3.76 \\
\hline
\end{tabular}


Eşbütünleşmenin varlığının araştırılması sonrasında, Granger nedensellik testine başvurularak çıktı ve işsizlik arasında bir nedensellik ilişkisinin olup olmadığı da sınanmaktadır. Seriler arasında uzun dönem eş bütünleşme olmadığından dolayı VAR modeline başvurulabilir. Ancak, bunun için, öncelikle VAR modelin uygun gecikme uzunluğunun tespit edilmesi gerekmektedir. VAR model için uygun gecikme uzunluğu Tablo 5'te özetlenmiştir. Tablo 5'te, LR, FPE, AIC ve HQIC bilgi kriterleri, uygun gecikme olarak 1'in seçildiğine işaret etmektedir.

Tablo 5. VAR Model için Uygun Gecikmenin Tespiti

\begin{tabular}{ccccccc}
\hline Lag & LL & LR & FPE & AIC & HQIC & SBIC \\
\hline 0 & 34.3212 & & 0.000736 & -1.53911 & -1.50878 & $-1.45636^{*}$ \\
1 & 40.8754 & $13.108^{*}$ & $.000652^{*}$ & $-1.66073^{*}$ & $-1.56974^{*}$ & -1.41249 \\
2 & 41.3808 & 1.0108 & 0.000771 & -1.49432 & -1.34268 & -1.08059 \\
3 & 42.355 & 1.9483 & 0.000894 & -1.35024 & -1.13793 & -0.771013 \\
4 & 43.3094 & 1.9089 & 0.001041 & -1.20521 & -0.932244 & -0.460496 \\
\hline
\end{tabular}

Gecikme seviyesi belirlendikten sonra yapılan VAR modeli ve Granger nedensellik sonuçları Tablo 6'da gösterilmiştir. Sonuçlara bakıldığında sıfır hipotezi olarak kurulan "Milli Gelir, İşsizliğin Granger nedeni değildir" ve "İsssizlik, Milli Gelirin Granger nedeni değildir" hipotezleri reddedilememiştir. Diğer ifadeyle iki değişken arasında iki yönde de nedensellik ilişkisi bulunamamıştır.

Tablo 6. Granger Nedensellik Test Sonuçları

$\begin{array}{llll}\text { HO Hipotezi } & \boldsymbol{F} & \text { Prob }>\boldsymbol{F} & \text { Karar } \\ \text { GDP İşsizliğin Granger nedeni değildir } & 0.01637 & 0.9838 & \text { Kabul } \\ \text { İşsizlik GDP'nin Granger nedeni değildir } & 0.21258 & 0.8094 & \text { Kabul }\end{array}$

Literatürde Okun yasasını test eden çalışmalar kadar ekonomik büyüme ve işsizlik arasında nedensellik ilişkisini araştıran çalışmalar da bulunmaktadır. Bu çalışmalarda özellikle gelişmekte olan ülkeler üzerine yapılan analizlerde sonuçların farklılaştığı görülmektedir (Hamia 2016; Ari 2016). Mısır için iki değişkeni ele alan ilk çalışmalardan olan Moosa (2008) değişkenler arasında zayıf bir ilişki tespit etmiş ve Okun katsayısını -0,001 olarak bulmuştur. Elshamy (2013), ise yapmış olduğu çalışmada Okun katsayısını 0,022 olarak tespit etmiş ancak nedensellik ilişkisini incelememiştir. Son dönemde yapılan bir diğer çalışmada Alhdiy et al. (2015) 2006-2013 dönemi çeyrek dönem verileriyle yaptı̆̆ çalışmada büyüme ve işsizlik arasında uzun ve kısa dönem ilişkiyi tespit etmeye çalışmıştır. Johansen eşbütünleşme ve Granger nedensellik testleriyle yapılan analizde uzun dönem eşbütünleşme ilişkisi olmadığı ifade edilmiştir. Kısa dönemde ise yalnızca işsizlikten büyümeye doğru bir nedensellik olduğu sonucuna ulaşılmıştır. Mısır için literatürde yer alan sonuçlara da bakıldığında işsizlik ve ekonomik büyüme veya çıktı arasında ilişkinin zayıf olduğu görülmektedir.

\section{Sonuç}

İşsizlik, birçok devlet için hem ekonomik hem de sosyal bir problem olarak iktisat politikalarının en başında ele alınan bir problemdir. Mısır devleti için de işsizlik problemi tarihsel süreçte önemini korumuş, her dönemde tartışılmış ve özellikle rejimin meşruiyeti ve sürekliliğinin sağlanması için önem arz etmiştir. Özellikle 2011 öncesinde emek piyasasında yaşanan gelişmeler, ayaklanmaların ortaya çıkmasında önemli bir rol oynamıştır. 1990 yılında IMF ile yapılan anlaşma çerçevesinde hayata geçirilen Ekonomik Reform ve Yapısal Uyum Programı (ERSAP), uzun bir süredir devam eden piyasa yapısında değişikliğe gidilmesine yol açmış ve serbest piyasa odaklı bir yaklaşıma geçilmesine sebep olmuştur. Bu yapısal değişim ve hayata geçirilen reformlar ekonomik büyüme üzerinde olumlu etkiler yapsa da emek piyasasında istenilen sonuçları vermemiştir.

2004 yılında Ahmed Nazif hükümetinin göreve gelmesiyle hızlanan neoliberal politikalarla özelleştirmeler artmış ve emek piyasasında yapısal dönüşümler meydana gelmiştir. Zorunlu emeklilik politikaları ve özelleştirmeler sonrası işten çıkarmalar işsizliğin artmasına neden olmuştur. Kamu sektörünün emek piyasasında ağırlığını azaltma yaklaşımı nedeniyle 2000’lerin ilk yarısına genç işsizlik oranı \%30’ları geçmiştir. Benzer bir süreç kadın işsizliği oranında da oluşmuştur. Yaşanan bu gelişmeler sonucunda işçi eylem sayılarında büyük bir artış meydana gelmiş, hükümete karşı toplumsal tepkiler de artmıştır. Neoliberal ekonomi politikalarının etkisiyle özelleştirmelere hız verilmesi ve kamu istihdamının azaltılmaya 
başlanmasıyla ortaya çıkan açığı özel sektör dolduramamıştır. Ekonomik büyüme istenilen düzeyde sağlanmış olsa da artan kayıt dışılık hem istihdam piyasasını etkilemiş hem de gelir artışı ve diğer sosyal haklardan faydalanılmasının önüne geçerek yoksulluk artışına neden olmuştur (Bargawi, 2014, 225). Nasır döneminde her üniversite mezununa iş garantisi politikası Mübarek döneminde kaldırılmıştır. Üniversite mezunu sayısı artmasına rağmen yeteri kadar istihdam firsatı oluşturulamamıştır (Abdih, 2011, 37). 2009 yılında toplam işsizliğin yüzde 35,5'ini, 2010 yılında ise \%39,7'si yükseköğrenim mezunları oluşturmaktadır. Diğer taraftan ortaöğretim düzeyinde eğitime sahip olanların payı da \%50'ye çıkmıştır (Worldbank, 2016).

1952 devrimiyle hayata geçirilen siyasal ve ideolojik araçlarla işçi hareketleri ciddi oranda kısıtlanmıştır. 1980’lerde yaşanan ekonomik problemlerin de etkisiyle ekonomi politikalarında meydana gelen yapısal etkilerle sendikal faaliyetleri ve işçi hareketleri daha da azalmıştır. İşten çıkarmalar, erken emeklilikler, kayıt dışı istihdam ile birlikte işçilerin harekete geçebilme kapasiteleri azalmış, ekonomik güvenlik sıkıntıları ile de birlikte ortak hareket kabiliyetleri kaybolmuştur (Bayat, 2002 s. 7). Ancak, giderek artan problemler nedeniyle tepkiler de büyümüștür. 1998-2003 y1lları arasında toplam 710 grev ve protesto yaşanmışken 2004 yılında sadece 265 eylem meydana gelmiştir. Daha çok tekstil sektöründe yoğunlaşan gre vler 2007 yılında ise zirve yaparak 614 eylemle birçok sektörde yaygınlaşmıştır (Beinin, 2009, s. 450). 2011 y1lında Tahrir Meydanında yaşanan eylemlerin ilk günlerinde de ön plana gençler ve emek grupları çıkmıştır.

Bu bağlamda, bu çalışmada Mısır için 1970-2016 yılları arasında işsizlik ve ekonomik büyüme arasındaki ilişki ele alınmaktadır. İlgili döneme ait yıllık veriler kullanılarak, işsizlik ve büyüme arasındaki negatif ilişkiyi öngören Okun Yasası ile test edilmiştir. Okun'un "açık" modeli araştırmada kullanılmış ve potansiyel değerler ile gerçekleşen değerler arasındaki açığın hesaplanması HP filtresinden istifade edilmiştir. Modelin hesaplanması sonucunda Mısır için zayıf bir ilişkinin olduğu sonucuna ulaşılmışıı. \%10 anlamlılık düzeyinde Okun katsayısı -0,081 olarak hesaplanmıştır. Ancak modelde yer alan test sonuçları ilişkinin zayıf olduğunu ortaya koymaktadır. Literatürde yer alan diğer çalışmalara paralel bir şekilde katsayı anlamlı çıkmış olsa da, Okun tarafından ortaya konan katsayının çok altında kalması nedeniyle, iki değişken arasında uzun dönem nedenselliğin sorgulanması için eş bütünleşme testi ve Granger nedensellik testi gerçekleştirilmiştir. $\mathrm{Bu}$ testler sonucunda, GSYİH ve işsizlik arasında uzun dönem eş bütünleşmenin ve iki yönlü de nedenselliğin olmadığg sonucuna ulaşılmıştır.

Okun denklemi ele alınarak yapılan analizde çok düşük de olsa katsayının anlamlı bulunmasına rağmen nedenselliğin olmaması Mısır ekonomik yapısı açısından daha anlamlı olduğu düşünülmektedir. Kamu sektörünün emek piyasasındaki etkinliği ve ekonomik performanstan bağımsız istihdam politikaları yürütmüş olması bu çıkarımın en önemli nedenlerindendir. Nasır'ın her üniversite mezununa iş sözüyle başlayan kamu etkinliği 2004 sonrası üretim sektöründe yavaşlamışsa da bürokrasideki işe alımlarla etkisini sürdürmektedir. Diğer taraftan, artan neoliberal politikalar sonucunda kamunun emek piyasasında etkinliğini azaltmaya çalışması sonuçlarını hızlı göstermiş, kadın ve genç işsizliğinde artışlar meydana gelmiştir. Öte yandan, ekonomik büyümenin de tüketime ve üretken olmayan sektörlere dayalı yapısı, büyüme sağlanmış olsa da istihdam oranlarının yeteri kadar artmasının önüne geçmiştir. Ekonomik reformların piyasaya daha fazla kaynak girmesini sağlamasıyla elde edilen yüksek büyüme oranlarının istihdam üzerindeki etkisi sınırlı kalmış̧ır.

Ayaklanmalar sonrası yaşanan ekonomik daralma sorunu yine kamu sektörünün büyük yatırımlarıyla aşılmaya çalışılmaktadır. Darbe sonrası yapılan Süveyş Kanal Projesi ve altyapı yatırımları son birkaç yıl için ekonomide düzelme yönlü bir hareketi oluşturmuştur. Ancak uzun dönemde yapısal reformların yapılması ve piyasaların düzenlenmesi gerekmektedir. Artan genç nüfusa istihdam imkânlarının sunulması ve gelir dağılımında yaşanan bozulmalarının önüne geçilmesi için emek piyasasının yeniden yapılandırılması gerekmektedir. Arap Ayaklanmalarının meydana gelmesinde önemli bir payı olduğu düşünülen işsizlik sorununun çözülmesi toplumsal refahın ve huzurun sağlanması için önem arz etmektedir. Dış kaynağa dayalı istihdam yaratmayan büyüme politikaları, uzun dönemde aynı sorunların yaşanmasına yol açacaktır. Reel sektöre dayalı ve emek yoğun sektörlerde yatırımların artırılması, aynı zamanda büyüyen genç ve kadın işgücüne öncelik verilmesi gerekmektedir. 
Eğri, T. / Journal of Yasar University, 2018, 13/49, 68-78

\section{KAYNAKÇA}

Abdih, Yasser. 2011. “Closing the Jobs Gap.” Finance \& Development 48 (2): 36-39.

Adanu, Kwami. 2005. “A Cross-Province Comparison of Okun's Coefficient for Canada.” Applied Economics 37 (5): $561-$ 70.

AfDB, and OECD. 2008. African Economic Outlook 2008. Paris: Organisation for Economic Co-operation and Development. http://www.oecd-ilibrary.org/content/book/aeo-2008-en.

Akay, Hülya Kanalıcı, Nejla Adanur Aklan, and Mehmet Çinar. 2016. "TÜRKIYYE EKONOMISINDDE EKONOMIK BÜYÜME VE İSSIZLLIK.” Yönetim ve Ekonomi Araștırmaları Dergisi 14 (1): 209-26.

Alhdiy, F. M., Johari, F., Daud, S. N. M., \& Rahman, A. A. (2015). "Short and Long Term Relationship between Economic Growth and Unemployment in Egypt: An Empirical Analysis." Mediterranean Journal of Social Sciences, 6(4), 454.

Alissa, Sufyan. 2007. "The Political Economy of Reform in Egypt: Understanding the Role of Institutions." Carnegie Papers 5. Washington, D.C: Carnegie Endowment for International Peace. http://carnegieendowment.org/files/cmec5_alissa_egypt_final.pdf.

Ari, Ayşe. 2016. “Türkiye'deki Ekonomik Büyüme ve İşsizlik İlişkisinin Analizi: Yeni Bir Eşbütünleşme Testi.” Siyaset,

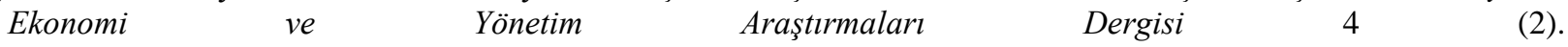
http://www.siyasetekonomiyonetim.org/index.php/seyad/article/view/412.

Arshad, Zeeshan. 2007. "The Validity of Okun's Law in the Swedish Economy." Stockholm: Stockholm University.

Attfield, Clifford L. F., and Brian Silverstone. 1997. "Okun's Coefficient: A Comment." The Review of Economics and Statistics 79 (2): 326-29. doi:10.1162/003465397556692.

1998. "Okun's Law, Cointegration and Gap Variables." Journal of Macroeconomics 20 (3): 625-37. doi:10.1016/S0164-0704(98)00076-7.

Ball, Laurence, Davide Furceri, Daniel Leigh, and Prakash Loungani. 2016. "Does One Law Fit All? Cross-Country Evidence on Okun's Law." http://unassumingeconomist.com/wp-content/uploads/2016/08/cross-country-evidenceon-okun-sep-2016-paris-workshop-draft-with-tables-and-charts.pdf.

Bargawi, Hannah. 2014. "Economic Policies, Structural Change and the Roots of the 'Arab Spring' in Egypt." Review of Middle East Economics and Finance 10 (3): 219-246. doi:10.1515/rmeef-2014-0034.

Barişik, Salih, Emrah İsmail ÇEVIK, and Nüket KIRCI ÇEVIK. 2010. "Türkiye'de Okun Yasası, Asimetri İlişkisi ve İstihdam Yaratmayan Büyüme: Markov-Switching Yaklaşımı.” Maliye Dergisi, no. 159 (Temmuz-Aralık): 88102.

Bayat, A. (2002). Activism and Social Development in the Middle East. International Journal of Middle East Studies, $34(1), 1-28$.

Beaton, Kimberly. 2010. “Time Variation in Okun's Law: A Canada and U.S. Comparison.” Bank of Canada Working Paper. http://www.bankofcanada.ca/wp-content/uploads/2010/05/wp10-7.pdf.

Beinin, J. (2009a). Workers' Protest in Egypt: Neo-liberalism and Class Struggle in 21st Century. Social Movement Studies, 8(4), 449-454. https://doi.org/10.1080/14742830903234320

Berger, T., Everaert, G., \& Vierke, H. 2016. "Testing for time variation in an unobserved components model for the U.S. economy." Journal of Economic Dynamics and Control, 69 (Supplement C), 179-208. https://doi.org/10.1016/j.jedc.2016.05.017

Christopoulos, Dimitris K. 2004. "The Relationship between Output and Unemployment: Evidence from Greek Regions*." Papers in Regional Science 83 (3): 611-20. doi:10.1111/j.1435-5597.2004.tb01928.x.

Coen, Robert M., and Bert G. Hickman. 2006. "An Econometric Model of Potential Output, Productivity Growth, and Resource Utilization.” Journal of Macroeconomics 28 (4): 645-64. doi:10.1016/j.jmacro.2005.01.002.

Çondur, F., \& Bölükbaş, M. (2014). Türkiye'de İşgücü Piyasası ve Genç İşsizlik-Büyüme İlişkisi Üzerine Bir İnceleme. Amme İdaresi Dergisi 47(2), 77-93.

Durech, Richard, Alexandru Minea, Lavinia Mustea, and Lubica Slusna. 2014. “Regional Evidence on Okun's Law in Czech Republic and Slovakia." Economic Modelling 42 (October): 57-65. doi:10.1016/j.econmod.2014.05.039.

Economou, A., \& Psarianos, I. N. (2016). Revisiting Okun's Law in European Union countries. Journal of Economic Studies, 43(2), 275-287. https://doi.org/10.1108/JES-05-2013-0063

El-Megharbel, Nihal. 2008. "The Impact Of Recent Macro And Labor Market Policies On Job Creation In Egypt." In Egyptian Economy: Current Challenges and Future Prospects, edited by Hanaa Kheir-El-Din, 179-200. Cairo: The American University in Cairo Press.

Elshamy, Hany. 2013. "The Relationship Between Unemployment and Output in Egypt." Procedia - Social and Behavioral Sciences, World Congress on Administrative and Political Sciences, 81 (Supplement C): 22-26. doi:10.1016/j.sbspro.2013.06.381.

Eser, Burcin Yılmaz. 2014. "Ekonomik Büyüme ve İşsizlik İlişkisi: Türkiye Örneği.” The Relationship Between Economic Growth and Unemployment: The Turkish Case. 9 (18): 26-47.

Fouquau, Julien. 2008. “Threshold Effects in Okun's Law: A Panel Data Analysis.” Economics Bulletin 5 (33): 1-14. 
Eğri, T. / Journal of Yasar University, 2018, 13/49, 68-78

Göçer, İsmet. 2015. “Okun Yasası: Türkiye Üzerine Bir Uygulama.” Uluslararası Ekonomik Araştırmalar Dergisi 1 (1): 112.

Hamia, Mohamad A. Abou. 2016. "Jobless Growth: Empirical Evidences from the Middle East and North Africa Region." Journal for Labour Market Research 49 (3): 239-51. doi:10.1007/s12651-016-0207-z.

Hooper, V. (2017). Okun's Law Revisited Within the Context of High Eurozone Unemployment: A Note. E-Journal of International and Comparative Labour Studies, 6(2). Retrieved from http://ejcls.adapt.it/index.php/ejcls_adapt/article/view/389

Ikram, Khalid. 2006. The Egyptian Economy, 1952-2000: Performance, Policies, and Issues. London; New York: Routledge.

Izyumov, Alexei, and John Vahaly. 2002. “The Unemployment-Output Tradeoff in Transition Economies: Does Okun's Law Apply?” Economics of Planning 35 (4): 317-31. doi:10.1023/A:1024441219635.

Grant, A. L. 2017. "The Great Recession and Okun's law." Economic Modelling. https://doi.org/10.1016/j.econmod.2017.10.002

Kızılgöl, Ö. (2006). Türkiye'de İhracata Ve Turizme Dayalı Büyüme Hipotezinin Analizi: Eşbütünleşme Ve Nedensellik İlişkisi. Akademik Bakış, (10), 1-19.

Lee, Jim. 2000. “The Robustness of Okun's Law: Evidence from OECD Countries.” Journal of Macroeconomics 22 (2): 331-56. doi:10.1016/S0164-0704(00)00135-X.

Loría, Eduardo, and Leobardo de Jesús. 2007. "The Robustness of Okun's Law: Evidence from Mexico. A Quarterly Validation, 1985.1-2006.4.” http://www.economia.unam.mx/profesores/eloria/PDFs/Articulos/the_robustness_ofokuns_law.pdf.

Malec, Karel, Shereen Gouda, Elena Kuzmenko, Daryoush Soleimani, Helena Řezbová, and Petra Šánová. 2016. "GDP Development and Employment in Egypt (2000-2013)." International Journal of Economics and Financial Issues 6 (1): 199-206.

Moosa, I. 2008. “Economic Growth and Unemployment in Arab Countries: Is Okun's Law Valid?” Journal of Development and Economic Policies 10 (2): 7-24.

Moosa, Imad A. 1997. “A Cross-Country Comparison of Okun's Coefficient.” Journal of Comparative Economics 24 (3): 335-56. doi:10.1006/jcec.1997.1433.

. 1999. "Cyclical Output, Cyclical Unemployment, and Okun's Coefficient A Structural Time Series Approach." International Review of Economics \& Finance 8 (3): 293-304. doi:10.1016/S1059-0560(99)00028-3.

Mucuk, M., Edirneligil, A., \& Gerçeker, M. (2017). The Relationship Between Unemployment Rate and Economic Growth: The Case of Turkey. Siyaset, Ekonomi ve Yönetim Araştırmaları Dergisi, 5(1): 1-8.

Okun, Arthur M. 1962. “'Potential Gnp: Its Measurement and Significance." In Proceedings of the Business and Economic Statistics Section of the American Statistical Association, 89-104.

Petkov, Boris. 2008. "The Labour Market and Output in the UK - Does Okun's Law Still Stand?” Bulgarian National Bank. http://www.bnb.bg/bnbweb/groups/public/documents/bnb_publication/discussion_2008_69_en.pdf.

Prachowny, Martin F. J. 1993. "Okun's Law: Theoretical Foundations and Revised Estimates." The Review of Economics and Statistics 75 (2): 331-36. doi:10.2307/2109440.

Silverstone, Brian, and Richard Harris. 2001. "Testing for Asymmetry in Okun's Law: A Cross-Country Comparison." Economics Bulletin 5 (2): 1-13.

Şenturk, M., \& Akbas, Y. E. 2014. İşsizlik-Enflasyon Ve Ekonomik Büyüme Arasindaki Karşilikli Ilişsinin Değerlendirilmesi: Türkiye Örneği. Journal of Yaşar University, 9(34), 5820-5832. https://doi.org/10.19168/jyu.43548

Tatoğlu, Ferda Yerdelen. 2011. "The Long and Short Run Effects between Unemployment and Economic Growth in Europe,” January. http://openaccess.dogus.edu.tr/handle/11376/280.

Villaverde, José, and Adolfo Maza. 2009. "The Robustness of Okun's Law in Spain, 1980-2004." Journal of Policy Modeling 31 (2): 289-97. doi:10.1016/j.jpolmod.2008.09.003.

Viren, Matti. 2001. "The Okun Curve Is Non-Linear.” Economics Letters 70 (2): 253-57.

Weber, Christian E. 1995. "Cyclical Output, Cyclical Unemployment, and Okun's Coefficient: A New Approach." Journal of Applied Econometrics 10 (4): 433-45. doi:10.1002/jae.3950100407.

World Bank. 2016. "Egypt, Arab Rep. | Data.” Accessed January 29. http://data.worldbank.org/country/egypt-arab-republic.

Yilmaz, D. O. G. (2005). Turkiye Ekonomisinde Buyume ile Issizlik Oranlari Arasindaki Nedensellik Iliskisi. Istanbul University Econometrics and Statistics E-Journal, 2(1), 63-76. 